\title{
Experiencing English: A Textbook Evaluation on the Cultural Loads
}

Received: $27^{\text {th }}$ February 2019; Revised: $05^{\text {th }}$ August 2019; Accepted: $30^{\text {th }}$ November 2019

Permalink/DOI: http://dx.doi.org/10.15548/jt.v26i3.555

Yunita Dewi Wahyuni

Universitas Syiah Kuala

Banda Aceh, Indonesia

Email: yunita@gmail.com

\section{Novalia Rizkanisa}

Universitas Syiah Kuala

Banda Aceh, Indonesia

Email: novalia1@gmail.com

\section{Iskandar Abdul Samad ${ }^{*}$ \\ Universitas Syiah Kuala \\ Banda Aceh, Indonesia \\ Email: Iskandar.abdul.samad@unsyiah.ac.id}

\section{Bukhari Daud}

Universitas Syiah Kuala

Banda Aceh, Indonesia

Email: bukharidaud@gmail.com

\begin{abstract}
This research aimed at investigating the cultural contents implied in the English textbook entitled Experiencing English. A qualitative method was used in this research which analyzed the English textbook. The data source of this research was the English textbook for Junior High School students entitled Experiencing English. The instrument used for collecting data was only from documentation in form of textbook. Then the data were analyzed by using Byram et al. (1994) framework to investigate the aspects of culture. In this research analyzed the nine aspects that have to be included in the EFL textbook. The result showed that stereotypes and national Identity is more frequently used in experiencing English. This aspect represents the target culture stereotypes and national identity which is commonly focused on the British and American culture. Finally, the conclusion led to the cultural content that is frequently used in Experiencing English textbook is target language culture. Notwithstanding, the source/local culture values as drafted in the 2013 Curriculum is still implied in the textbook as intended to enable the students to reflect their own culture in English.
\end{abstract}

\section{*) Corresponding Author}

Keywords: Cultural contents; target language; English textbook.

How to Cite: Wahyuni, Y., Rizkanisa, N., Samad, I., \& Daud, B. (2020). Experiencing English: A textbook evaluation on the cultural loads. Al-Ta Lim Journal, 26(3). doi:http://dx.doi.org/10.15548/jt.v26i3.555

\section{INTRODUCTION}

There are several factors contributing to the students' success in language learning, one of them is textbooks. The presence of a textbook is important for language learners besides the presence of a teacher who has cultural knowledge. Textbooks may serve as helpful tools to guide teachers. Most probably, the textbooks include several activities, exercises, or tasks which can be used by the teachers while conveying their lessons (Arslan, 2016).
Realizing the textbook used as the only instructional materials in teaching learning process specifically in Indonesia, it is important to take the content of textbooks into consideration. English foreign language textbook should contain cultural content from the target language. Undoubtedly, foreign language learners will have a great appeal for learning target language, English, if the culture of target language also taught at the same time. As Cakir (2010) asserts that language textbooks should provide cultural elements in order foreign language learners can reach the 
authentic language appropriately involving some cultures that are commonly used in target language communication.

In fact, the students cannot truly learn the language well until they have also mastered the cultural contexts in which the language occurs (Choudhury, 2013). Therefore, the language teachers are required to consider in inserting the cultural background and features in the foreign language classroom since the culture and language learning strongly link to each other (Dai, 2011). Thus, English are taught without differ its culture (Sardi, 2002).

Due to the inseparable relationship between language and culture, there has been an increase in the number of language educators who emphasize the significant role of culture in the ELT classroom. For instance, Abolghasem (2010) points out that the teaching of culture in foreign language classroom enhanced the students to understand and aware of culture of that language. Furthermore, target language culture (British and American) are taught along with English (Byram \& Fleming, 1998). Hence, learning a language without culture is fluent fool where someone who speaks a foreign language well, but does not understand the cultural background of the language (Bennett, 1993).

Truly, the culture of Western and Eastern are quite different. They express different meaning even using the language in the same form. For instance, when Western people express the word dinner, they may be referring to hotdog or pizza. While the Eastern culture, specifically Indonesia, dinner might refer to rice. In other words, misunderstanding occurred if people do not understand each other culture (Tseng \& Chao, 2012).

Essentially, learning a language does not merely learn how to memorize the vocabulary or the grammatical rules but more than that. Learning a language also entails learning about its culture. As Silberstein (2001) asserts to be able to speak a language appropriately not only by mastering grammatical knowledge, but also the learners need a good deal of exposure to that language's culture. That is to say, learners need to know how the language works. Learners are required to be able to use the language properly at one occasion and to decide what exactly to express with others at different times.

Foreign language learners need to learn culture of the target language particularly English, in order to avoid the significant problems when interacting with the native speakers. In other words, for foreign learners, language seems senseless if they know nothing about the people who speaks the target language (Pulverness, 2003). Furthermore, McDevitt (2004) proposes that learning foreign language is a challenge to figure out the nature of another people. Learners can develop positive attitudes and come to be more tolerant of other cultures when they acquire certain cultural knowledge. Tomalin (2008) suggests while teaching foreign language in the classroom, cultures are taught as a fifth language skill besides listening, speaking, reading, and writing, in order to know how to use English in the right ways, understand and appreciate the values of other cultures.

Admittedly, language and culture are strongly connected and cannot be isolated from each other. Every lesson is about something, and that something is cultural (Valdes, 1990). Nevertheless, the main question is always regarding on which culture to be taught in the classroom. Considering the inseparable of culture and language, it is hard to imagine teaching a foreign language without dealing with its culture. Language and culture are acquired together, therefore, language would be dead without culture, and culture would have no shape without language (Jiang, 2000).

Considering the explanation given above, both practitioners and theorists have some different ideas about the issue. Some of them state that English are taught referring to its culture by giving more emphasis on the American and the British culture which are called target culture. Bada (2000) claims that target culture must be the only focus while learning the target language. The learners 
cannot understand the language logically without inserting culture of that language as language and culture are intricately interwoven so both of them cannot be separated. He states language learners faced some problems in communicating meaning with native speakers when they unexposed to that target culture. Therefore, learners have to highlight how native speaker of target culture use language under certain circumstances.

Corbett (2003) also states the learners need to be able to understand the target culture if they want to achieve high proficiency in the target language. Thus, understanding how a community of target culture uses a language, it is necessary to understand its cultural backgrounds. Similarly, Santosa (2015) also suggests the lack of target language culture leads the cultural gap. Teaching culture may enable students to be familiarized with that language which would help them explore the language in context. In contrast, there are views that rejected the idea of teaching target language culture along with English (Kramsch \& Sullivan, 1996; McKay, 2003). They believed that while foreign learners learn the target language culture in the classroom, learners will be more likely to compare their local culture with the target language culture, western culture. Consequently, it may trigger dissatisfaction. It is why textbooks play an important role today since the teachers use them as the most important tool in teaching. In fact, textbook is not only as the tool, but it is even also as the targets of action.

Notwithstanding, there is no perfect textbook, thus, the evaluation needs to be conducted. One of the concerns may focus on the cultural content attached in textbooks. Therefore, this study intended to investigate which aspects of culture were introduced in English foreign language textbook for second year students of junior high school entitled "Experiencing English" under 2013 curriculum. Based on the research background, the research attempts to answer the research question formulated as follows: what aspects of culture are more frequently used in "Experiencing English" textbook for $8^{\text {th }}$-grade students of Junior High School under the 2013 curriculum? Therefore, this research is intended to investigate the aspects of culture which are more frequently used in "Experiencing English" textbook for $8^{\text {th }}$-grade students of Junior High School under the 2013 curriculum.

\section{Effective English Textbook}

Particularly, textbook serves as media that helps the teachers in arranging the instructional process (Ur, 2009). There are many English textbooks used by the teacher which promotes every unique material in those books. Actually, this research only focuses on English foreign language textbook for second year students of junior high school entitled "Experiencing English" under 2013 curriculum. Specifically, it is important to examine about the effective English textbook used by the teacher. Crawford (2002) reveals that effective textbooks have to be included two criteria. First, it must contextualize the language in which language whether the input or learner output should be real from the context occurred. Textbook must provide meaningful and familiar context materials for the learner to help them use language as media of communication. Second, the materials should emphasize the use of language without ignoring the important of the language form. Third, the materials served need to be authentic and realistic rather than contrived and artificial language materials. Particularly, English textbook have to lay the cultural content in it.

\section{Culture in English Language Textbook}

As stated by Wardhaugh (2006) that language determines thought and culture. It means that culture influences people's language. Consequently, someone who learns language beside their first language means that they also acquire the culture of the language. National Education in Indonesian System suggests the teachers' responsibility to maintain the Indonesian national culture, the values of religion and local wisdoms. As textbooks are generally considered to be the 
major source of the teaching materials, they have an important role in integrating cultures or cultural elements in the instructional process. That is why culture is an important aspect in ELT textbooks.

Nowadays, EFL learners are demanded to acquire both target language and culture. This demand becomes part of the communicative competence which includes cultural understanding, conversational routines, and the target society's norms and values. Numerous studies have proven that ELT textbooks have contained representations of culture and society. There are also many studies about ELT textbook evaluation done by scholars. One of them is done by Hermawan and Noerkhasanah (2012) who analyzed English textbooks for primary school published by Erlangga "Grow with English 4, 5 , and 6." The result showed that culture in this context is perceived in terms of Aesthetic Sense, Sociological sense, Semantic Sense, and Pragmatic (Sociolinguistic). As stated by some scholars that textbooks play an important role in developing cultural attitudes (Hatoss, 2004). Actually, the textbooks are commercially available in various types. English language teaching for foreign learner should aim at developing intercultural awareness in a broader context. That is why textbook evaluation is of paramount importance to do. As done by Hatoss (2004), she believes that the success of the textbooks in providing appropriate support for language learners in enhancing intercultural skill.

\section{Criteria for Cultural Content in Textbook Evaluation}

Various textbook evaluation checklists have been provided to help teachers to choose teaching materials that best meet the aims of the course as well as the needs of students. One of the most prominent researchers on intercultural learning and cultural content in the classroom is by using the framework of Byramet al. (1994).

Focusing on cultural content in foreign language textbooks, they have published a list of criteria examining the extent and methods of how culture is presented. These include sociological factors such as social class and social interaction, and historical and geographical aspects. Further categories are stereotypes and national identity i.e. if 'typical' national symbols appear in the textbook. It also includes more aspects on society, addressing various cultural sectors. Hence, these criteria are far more in-depth and critical. Furthermore, there is also a focus on beliefs and behaviour (e.g. moral, religious) and ethnic minorities. Byram et al. (1994) agree on more cultural input and/or facts should be in teaching materials and declares nine aspects focusing on cultural content tobe included in textbooks as described in the table below.

Table 1. Nine Aspects for Analyzing the Content of Cultural Learning

\begin{tabular}{|c|c|}
\hline No & $\begin{array}{c}\text { The Aspects of Cultural Content in the } \\
\text { Textbook }\end{array}$ \\
\hline 1 & $\begin{array}{l}\text { Social identity and social group (social class, } \\
\text { regional identity, ethnic minorities) }\end{array}$ \\
\hline 2 & $\begin{array}{l}\text { Social interaction (differing levels of formality; } \\
\text { as outsider and insider) }\end{array}$ \\
\hline 3 & $\begin{array}{l}\text { Belief and behaviour (moral, religious beliefs; } \\
\text { daily routines) }\end{array}$ \\
\hline 4 & $\begin{array}{l}\text { Social and political institutions (state } \\
\text { institutions, health care, law and order, social } \\
\text { security, local government) }\end{array}$ \\
\hline 5 & $\begin{array}{l}\text { Socialization and the life cycle (families, } \\
\text { schools, employment, rites of passage) }\end{array}$ \\
\hline 6 & $\begin{array}{l}\text { National history (historical and contemporary } \\
\text { events seen as markers of national identity) }\end{array}$ \\
\hline 7 & $\begin{array}{l}\text { National geography (geographical factors seen } \\
\text { as being significant by members) }\end{array}$ \\
\hline 8 & $\begin{array}{l}\text { National Cultural Heritage (the cultural } \\
\text { artefacts, which are known to the members of } \\
\text { the nation) }\end{array}$ \\
\hline 9 & $\begin{array}{l}\text { Stereotypes and national identity (what is } \\
\text { "typical" symbol of national stereotypes). }\end{array}$ \\
\hline
\end{tabular}

\section{METHOD}

This research is designed qualitatively. Particularly, content analysis is used in this research. Further, content analysis is defined as the process of summarizing and reporting written data, the main content of the data and their messages (Cohen, Manion, \& Morrison, 2007, p. 475). The source of data in this research is the English textbook. The researcher chose the English textbook entitled 
"Experiencing English" textbook for $8^{\text {th }}$-grade students of Junior High School under the 2013 curriculum. "Experiencing English" is an EFL-textbook, which is one of the English textbook used in Indonesian secondary education with eight graders. The rationale behind this book selection because the researcher has used this book in teaching and the researcher finds its cultural content interesting. The book is also rather new because it is created based on the 2013 curriculum.

In this research, the researcher used the documentation checklist. The documentation checklist used in this research covers the cultural aspects by Byram et al. (1994) such as social identity, social interaction, belief and behavior, national history, national identity, national heritage, and the stereotypes. Indeed, this analysis clearly becomes a good tool to analyze the cultural content in the English textbook selected. Then, the analysis leads to the firm research result.

\section{RESULT AND DISCUSSION}

This research was a content analysis study to reveal the cultural contents in English textbooks for junior high school entitled "Experiencing English" for Junior High School Students, Year VIII. Below is the explanation of the result of this research.

\section{Frequent aspects of culture in "Experiencing English" Textbook}

The researcher investigated the cultural aspect which is more frequently used in "Experiencing English" textbook for $8^{\text {th }}$-grade students of Junior High School under the 2013 curriculum. The analysis is divided into nine criteria. Below is the description of the cultural aspect found in the textbook which is showed in the following table.

Table 2. The Description of the Cultural Aspect Found in the Textbook

\begin{tabular}{|c|c|c|c|c|}
\hline No & Byram' s Criteria & Details & Position & Frequency \\
\hline 1. & $\begin{array}{l}\text { Social Identity and } \\
\text { Social Group }\end{array}$ & $\begin{array}{l}\text { - Dialogue (On a Train \& At the bus Station) } \\
\text { - Picture of the poor girl } \\
\text { - Dialogue about Nelson Mandela and Obama } \\
\text { - Western Physical look } \\
\text { - Passage about My family Description } \\
\text { - The picture of a magician } \\
\text { - The picture of western singer } \\
\text { - Famous International Singer }\end{array}$ & $\begin{array}{l}\text { Page } 7 \\
\text { Page } 23 \\
\text { Page } 90 \\
\text { Page } 137 \\
\text { Page 161 } \\
\text { Page } 193 \\
\text { Page 202 }\end{array}$ & 8 \\
\hline 2. & Social Interaction & $\begin{array}{l}\text { - Getting and Paying Attention } \\
\text { - What you want to Make sure someone understand you } \\
\text { - When you congratulate Someone } \\
\text { - When you ask for opinion } \\
\text { - When you give and respond to compliments } \\
\text { - When you encourage someone } \\
\text { - When you console someone } \\
\text { - Instruction and Direction } \\
\text { - Invitation } \\
\text { - Prohibition } \\
\text { - When you ask and refuse for Permission } \\
\text { - When You take,ask, and leave the message }\end{array}$ & $\begin{array}{l}\text { Page } 7 \\
\text { Page } 11 \\
\text { Page } 19 \\
\text { Page } 25 \\
\text { Page } 31 \\
\text { Page } 32 \\
\text { Page } 32 \\
\text { Page } 53 \\
\text { Page } 56 \\
\text { Page } 64 \\
\text { Page } 69 \\
\text { Page } 124\end{array}$ & 12 \\
\hline 3. & Belief and Behaviour & $\begin{array}{l}\text {-Dialogue about burping } \\
\text { - Dialogue about friends } \\
\text { - Dialogue about Accident } \\
\text { - Pigeon in Western Countries } \\
\text { - Cars are packed like sardines } \\
\text { - Passage about bedtime story } \\
\text { - Mouse deer and tiger } \\
\text { - The fox and the crow }\end{array}$ & $\begin{array}{l}\text { Page } 13 \\
\text { Page } 25 \\
\text { Page } 42 \\
\text { Page } 106 \\
\text { Page } 117 \\
\text { Page } 172 \\
\text { Page } 176 \\
\text { Page } 179\end{array}$ & 12 \\
\hline
\end{tabular}




\begin{tabular}{|c|c|c|c|c|}
\hline & & -Landi and his spikes & Page 180 & \\
\hline No & Byram's Criteria & Details & Position & Frequency \\
\hline 4. & $\begin{array}{l}\text { Social and political } \\
\text { institution }\end{array}$ & $\begin{array}{l}\text {-Picture of Prohibition Sign } \\
\text {-Picture Announcement } \\
\text {-Passage about Botanical Garden } \\
\text { - British Airways }\end{array}$ & $\begin{array}{l}\text { Page } 66 \\
\text { Page } \\
120-121 \\
\text { Page } 149 \\
\text { Page } 155\end{array}$ & 4 \\
\hline 5. & $\begin{array}{l}\text { Socialization and life } \\
\text { cycle }\end{array}$ & $\begin{array}{l}\text { - The House (it describes about flat and living with Canadian } \\
\text { friend) } \\
\text {-Passage about Pigeon } \\
\text {-Picture and Passage about western kitchen }\end{array}$ & $\begin{array}{l}\text { Page } 94 \\
\text { Page } 106 \\
\text { Page } 114\end{array}$ & 3 \\
\hline 6. & National History & $\begin{array}{l}\text { - The History of Greeting Cards } \\
\text { - The History of The palace of Westminster } \\
\text { - Jatim Park in East Java } \\
\text {-Picture of Candi Borobudur } \\
\text { - Passage about Toraja Funeral } \\
\text { - The history of Eric Clapton song Tears in Heaven }\end{array}$ & $\begin{array}{l}\text { Page } 84 \\
\text { Page } 89 \\
\text { Page } 104 \\
\text { Page } 140 \\
\text { Page } 148 \\
\text { Page } 205\end{array}$ & 6 \\
\hline 7. & National Geography & $\begin{array}{l}\text { - The English Speaking Countries } \\
\text {-Passage about Mount Bromo } \\
\text {-Passage about Bali } \\
\text {-Passage about London }\end{array}$ & $\begin{array}{l}\text { Page } 146 \\
\text { Page } 147 \\
\text { Page } 224\end{array}$ & 4 \\
\hline 8. & $\begin{array}{l}\text { National Cultural } \\
\text { Heritage }\end{array}$ & $\begin{array}{l}\text { - Dialogue about movie } \\
\text { - The Lion and The Gnat } \\
\text { - The Crow and The pitcher } \\
\text { - Songs and Musicians }\end{array}$ & $\begin{array}{l}\text { Page } 55 \\
\text { Page } 190 \\
\text { Page } 226 \\
\text { Page } \\
195-221\end{array}$ & 4 \\
\hline 9. & $\begin{array}{l}\text { Stereotypes and } \\
\text { National identity }\end{array}$ & $\begin{array}{l}\text { - Picture of President Indonesia } \\
\text { - Dialogue about gado-gado } \\
\text { - Western Name } \\
\text {-Indonesian Name } \\
\text { - Western Invitation Card } \\
\text { - Western Greeting Cards } \\
\text { - Indonesian Greeting Cards } \\
\text { - The London Eye } \\
\text { - Picture of free pigeon in park } \\
\text { - Prohibition sign about Donot feed pigeon } \\
\text { - The symbol of Poundsterling and Dollar } \\
\text { - The symbol of time am/pm } \\
\text { - Picture of England phonebox } \\
\text { - Meadow Gold Ice Cream } \\
\text { - The Milkmaid and Her Bucket } \\
\text { - America and British Stereotypes } \\
\text { TOTAL }\end{array}$ & $\begin{array}{l}\text { Page } 17 \\
\text { Page } 51 \\
\text { Page } 58 \\
\text { Page } 87 \\
\text { Page } 88 \\
\text { Page } 91 \\
\text { Page 109 } \\
\text { Page } 116 \\
\text { Page } 117 \\
\text { Page } 123 \\
\text { Page 132 } \\
\text { Page } 138\end{array}$ & 14 \\
\hline
\end{tabular}

\section{Social Identity and Social Groups}

This aspect discusses how the social class, regional identity, ethnic minority, and professional identity are presented in the textbook. Social classes are apply in this textbook which the picture of the cute little girl standing on the garbage (Page 23). Social identities are also mainly discussed in the textbook by presenting people with different job and skill. For instance on page 5-7, there are a dialogues and pictures of police officer and the woman, the seller and the man, the famous international singer, the magician, president, and soon. Dialogue about Nelson Mandela and Obama is also shared the ethnic identity where both are including the black people. Nelson Mandela is African and Obama is Afro-American/African American. Then, the passage about "My Family Description" (page 137) highlights the family in English speaking country with their 
western physical look. It is mostly described by giving example of blonde hair, a red curly hair, and blue eyes. There are a phrase where stated that "My sister is an English rose she's got fair hair and fair skin." In summary, the social identity and social group were explained by presenting people with different backgrounds and standard of living. Furthermore, the identities also were mainly discussed based on their physical look and mentioning some professions.

\section{Social Interaction}

This aspect presents the convention of verbal and non-verbal behaviour in social interaction, situation of interaction, subjectivity of characters, and formal and informal interaction that is put in the textbook. The verbal behaviour that is shared in this textbook is people of English speaking country love to start saying "Well actually, Well, I Think, Well,.." when they are answer someone's questions.

Actually, there are some interactions in the textbook such as asking direction in the street, asking the time with the strangers, the discussion between a customer and the shopkeeper, the interaction between the tour guide and the tourist, and a formal interview. All these interaction are called situation of interactions. Furthermore, the social interaction in this textbook is also mainly presented to figure it out the nature of interaction. This shared about formal or informal, and subjective between the friends or relatives. For instance when a girl/boy is talking with their friends, then the style of the language used is rather informal. It is due to their close relationship. However, close relationship does not merely make them speaking informally. As can be seen on the page 13, the interaction between a teacher and his students are also less formal (Stare at you? I don't quite follow you. Could you be more explicit?).

Additionally, the model dialogues in this textbook are very objective and easy to follow. The convention of formal and informal interaction is quite understandable by the learners. Especially in the textbooks for secondary education, this book served several model dialogues given for thelearners. The learners are supposed to practice with their partner in common situations of interaction, which they could face while travelling in English-speaking countries.

\section{Belief and Behaviour}

The example of daily life routine within social group, the moral and religious belief is summarized in this aspect. The habit that is appeared in this textbook is on page 13. It shares about the eating habit in British culture which is burping is not acceptable during the meal. But, this eating habit is acceptable in Nigerian culture.

Next is on page 25 which 2 people talk about friendship. It explicitly shares the American proverb "One Little Lie and Friendship just disappear" which mean honesty is the crucial thing in friendship. The social behaviour is showed in the dialogues between Alan and Mila. Alan is very sad and gives his deepest condolence to Mila because her grandmother passed away. Both are the behaviour that should be learned by the students. Another phrase that is told in the textbook is on dialogue page 117. It is about the parking lot which tells about "The cars are parked like sardines in there". It is the idiom that is used in British way to express the crowded parking situation.

The belief that is poured in this textbook is about Pigeon on page 106-109. As we now that English speaking countries have the feral pigeon in public space. They believe that the pigeon represent the natural wildlife. Actually, this outlook is rare in Indonesia. Moreover, page 172 showed the bedtime story is a tradition in English speaking countries where the parents tell a story such as fable, legend, fairy tale to their children before going to sleep. It is kind of daily routine in English speaking countries. The other daily routines in this textbook are mainly showed through national holiday, shopping, going to the cinema and sports. 
Importantly, the moral value is mainly discussed in the reading passages on page 172-191. Those reading passages are in form of fables, fairy tales, and so on. Every passage contains a deep moral value that can be applied in the real life. In brief, this aspect served some social behaviour and belief that commonly used in English speaking countries. Having an awareness of this aspect can make the foreign language students have the intercultural competence.

\section{Social and Political Institutions}

An awareness of having differences in social and political institution seems important to be dealing with. In the textbooks analyzed, there are only few references to the socio-political institutions and most of them are only mentioned by name and their meaning for the English speaking country society is not discussed further. The example mentioned is the picture of the prohibition sign on page 66. Based on those sign, the students can have knowledge about the sign in the English speaking countries.

Botanical garden is the institution that appears in the textbook. It told about the spots in that place. The last institution appears is British Airways which is only mentioned without explanation, but it seems enough to be consider as a way to introduce the target culture.

\section{Socialization and the Life Cycle}

Socialization and the life cycle discuss about families, schools, employment, and rites of passage. In the textbook, it is presented well on page 94 . The reading passage about is "My House". The passage told about a western man/woman that lives in a flat. She/he lives with his/her friends from Canada. In the passage, she/he describes their flat in detail. This description can be a new knowledge for foreign learner. Moreover, on page 114 also shares the characteristic of English speaking countries namely modern kitchen. In English speaking country, their kitchen is more modern than in Indonesia. The passage described the kitchen with its sophisticated utensils, such as juice marker, bread box, coffee maker, sink, and even they put flower vas in their kitchen.

After that, the passage about pigeon on page 106 also represents the life cycle. In English speaking countries, the open public space is famous for their feral pigeons and feeding them is very popular activity. Therefore, many families visit the open public space to feel that environment. Besides, education is also including in life cycle. In the textbook, educational term is presented on page 32, such as The Oxford admission test, TOEFL score, and TOEIC score. In conclusion, this aspect represents some examples of English speaking countries life cycles and education. Both are presented well in the textbook.

\section{National History}

The national historical aspect is the historical and contemporary events seen as markers of national identity. The presentation of the national history in this textbook is on page 89. The picture of the palace of Westminster represents the national history in United Kingdom. It is the famous palace in the world for nearly 1000 years and people in England are very proud of this palace. The Big Ben is the part of the palace of Westminster. The Big Ben becomes the trend mark in London.

The other national histories in this textbook come from our country, Indonesia. The textbook presents Borobudurtemple and reading passage about Torajafuneral. Both are served in every detail to show the Indonesian culture, so the students still get their own culture.

In fact, national history is not only about historical place and building, but it is also about an historical event or story. On page 205 , there is a passage about the story behind the Eric Clapton song entitled Tears in Heaven. This song is created by him as a memorial song to his son, Conor. Conor died at four years old. He fell 59 storeys to his death from New York City flat. This song is 
one f Clapton's most famous. After that, he won six Grammy Awards in 1993. Another historical event is the history of greeting cards on page 84. It stated that Sir Henry Cole has been credited with establishing of printed cards. He quickly recognized the opportunity this printed greeting card could offer. He sold the first print in Central London. Briefly, the existence of this aspect in the English textbook can enlighten the foreign learners in having the target cultural knowledge.

\section{National Geography}

This aspect discusses the national geography that is presented in the textbook. The English speaking countries, United Kingdom, America, New Zealand, and Canada are mentioned in the textbook. The researcher also got the city that is mentioned in the textbook, such as Manchester, New York City, and London.

The nature of the London is well presented in the textbook in which is the capital city England and Great Britain. London has four major areas namely the city, the west end, the east end, and the south bank. The parks in London is also mentioned in this book, such as Kensington garden, Hyde park, Green park, St James park, and Regents park.

In conclusion, the national geography was mostly presented about London. The researcher found that these examples are important and interesting for the students to know. Besides, the Indonesian national geography is also mention in this textbook in form of reading passage, such as passage about Mount Bromo and Bali Island.

\section{National Cultural Heritage}

This aspect discusses the cultural artefacts, which are known to the members of the nation, such as Shakespeare in Britain. The examples that exhibit in the textbook show the popular culture in English speaking countries, such as musician, movies/movie stars, literatures, and film makers. As can be seen on page 55 , it is the dialogue about movie in the cinema entitled Deliver us from evil (Horror), and Earth to Echo (ScienceFiction).

The researcher also meets the Fables that are written by the famous author for children books, namely Aesop. $\mathrm{He}$ is a storyteller credited with a number of fables and now is commonly known as Aesop's Fable. The students get to read those fables because those imply good moral value and attitude.

Another popular culture that is mentioned in the textbook is English songs which become the trend in this age. Further, some musicians also mentioned in the textbook and even the legendary musicians are mentioned, namely John Lennon, Eric Clapton, and Jimmie Hendrix. Their songs are available in the textbook, so the students can sing a song together. Some new musician and their song lyric is also available in the textbook which can be enjoyed by the students, such as Speak Now (Taylor Swift), Fireworks (Katy Perry), Grenade (Bruno Mars), and many more.

\section{Stereotypes and National Identity}

This aspect is about of what is the typical symbol of national stereotypes. This aspect got the bigger percentage in the textbook. The researcher started to discuss this aspect by discussing about the characteristic of personal name in English speaking countries, such as Alan, Taylor, Mrs. O’Brian, Harry, Dave, and Ann. Those names are mentioned in the textbook. The symbol of currency in the textbook is also mentioned, such as Poundsterling ( $\mathfrak{f})$ and Dollar (\$). Further, the 12 hours clock format is used in this textbook in form of AM and PM. English speaking countries used this format for their time convention. Additionally, this textbook also presents the usage of the word in British and America. In America, this is pants, but it called "Trousers" in British.

Western invitation cards also include in this aspect. In the passage, some invitation cards use the term RSVP in invitation card. It 
is a process for a response from the invited person. This term is often in the formal invitation cards which need the information from the guest. Further, greeting cards is also the stereotypes that commonly used in English speaking countries. They used the greeting cards for the celebration or special event, such as Christmas card, thanksgiving card, Valentine's Day card, and soon. Besides, Indonesian culture does not know about this term.

The famous monuments of the United Kingdom get attention in this textbook in the form of reading passage. It is about the London eye, the Tower Bridge, and the Palace of Westminster. The London eye on page 91 is told to be a part of the year 2000 millennium celebrations. The London eye is situated right at the tourist heart of London. Again, the picture of free pigeon in open public space is the national identity in English speaking countries. The prohibition sign of "Do not feed the pigeon" is also a great attention in this textbook which the people obey the sign and let the pigeons search food from nature.

Surprisingly, the passage about Meadow Gold Ice Cream (page 132) got so much attention by the researcher. This ice cream is very famous in America which has produced in 100 years. It contains creams, butter, salt, sugar, fruit, and natural colouring. The stereotypes character also mentioned in this textbook that is a passage about The Milkmaid and Her Bucket" on page 138. The milkmaid seems familiar in English speaking countries, who was going to the market carrying the milk in a bucket. The milkmaid sells the milk in the market. The both passage represent the English speaking countries which can be knowledge for foreign learner. In fact, some Indonesian identity and stereotypes are also mentioned in this textbook, namely the picture of Indonesian president, the dialogue about Gado-gado, and Indonesian personal name. According to these results above, American and England culture was rather critically discussed at many points.
Textbook is very important parts in teaching and learning process. Both teachers and students, mostly, use them as the basic foundations in the classrooms. Textbooks may not be able to fulfil all the needs in the instructional process but their existence as teaching sources is still paramount. Therefore, this research investigated the cultural contents in English textbook entitled "Experiencing English". This textbook is for eighth grade students of junior high school. In this research question, it is analyzed only the reading passages, dialogues, and the pictures in the textbook by utilizing the framework by Byram et al. (1994) which proposed nine cultural aspects those have to be implied in English textbook. There are some aspects that reached similar proportion in "Experiencing English" textbook namely social interaction and belief and behaviour. It also found by Gunantar (2017) that social interaction reached the biggest proportion in Indonesian EFL textbook.

On the contrary, there are five aspects that get the lower proportion the textbook, namely Socialization and life cycle, National Geography, National History, Social and political institution, and National Cultural Heritage. What actually found by Tüm and Uğuz (2014) indicated that social identity/group; social and political institution; national geography; stereotypes and national identity got the lowest proportion. Those aspects are insufficiently added in the textbook analyzed.

Importantly, the noteworthy input that is drawn from the analysis about the cultural aspect and which is the one more frequently used in the textbook is Stereotypes and National Identity. There are 14 topics that determine Stereotypes and National Identity in Experiencing English. What has been done by Lappalainen (2011) also indicated a similar result of EFL Finnish textbook. On the contrary, Tüm and Uğuz (2014)in their study yielded different result that stereotypes and national identity did not found in the textbook analyzed. They found socialization and life 
cycle mostly applied in the English textbook in Turkey.

The research result has arrived at noteworthy insight that this research shared the cultural content in the textbook. The cultural aspect which is more frequently presented in "Experiencing English" is Stereotypes and National Identity. It can be summarized that "Experiencing English" textbooks mostly focused on the cultures of English-speaking countries or target culture, especially England. Similar research can b found in Yamanaka (2006) and Xiao (2010), where most cultural contents focused on the American and British culture.

\section{CONCLUSION AND RECOMMENDATION}

The analysis of the textbook has demonstrated the cultural content that is implying in the "Experiencing English" textbook for eighth grade students of Junior High school under 2013 curriculum. This research conducted by Byram et al. (1994) framework to analyze the data. They proposed nine aspects that have to be included in EFL textbook. The result showed that the most frequent aspects of culture used in "Experiencing English" textbook namely Stereotypes and National Identity. This aspect represents the target culture stereotypes and national identity which is commonly focused on the British and American culture.

Based on the result of the research, the researcher proposes some suggestions. The English teachers should be selective in choosing the best English textbook for teaching material. Due to the contents on intercultural interaction were seriously underrepresented in the current English textbooks. To improve the imbalance, English textbooks need to include more cultural materials that provide opportunities to compare the differences and similarities among various cultures and countries. The representation of culture-related content in the textbooks should be considered an essential part of teaching practices since language and culture cannot be separated in multicultural classrooms. In this respect, English teachers need to take an active role in redressing the imbalances in the representation of cultural materials by providing corrective feedback for authors. Since this research has its own limitation and has a small portion of the data, it is expected that this research can enlighten research idea for other researchers who would like to conduct similar research by employing more data. Even, the future research perhaps can make the comparison between Indonesian EFL textbook. Finally, the result of the research may offer positive contribution to those who have positive attitude toward this research.

\section{REFERENCES}

Abolghasem, S. H. F. (2010). Culture assisted language learning (CALL) and teaching general English. In $E A B R$ \& ETLC Conference (pp. 371376).Dublin, Ireland.

Arslan, S. (2016). An analysis of two Turkish EFL books in terms of cultural aspects. Procedia-Social and Behavioral Sciences, 232, 217-225.

Bada, E. (2000). Culture in ELT. Cukurova University Journal of Social Sciences, 6, 105.

Bennett, J. M. (1993). Cultural marginality: Identity issues in intercultural training. Education for the intercultural experience, 2, 109-135.

Byram, M., Morgan, C., \& Colleagues. (1994). Teaching and Learning Language and Culture. Great Britain: WBC.

Byram, M., \& Fleming, M. (1998). Language learning in intercultural perspective: Approaches through drama and ethnography. New York: Cambridge University Press.

Cakir, I. (2010). The frequency of culturespecific elements in ELT Textbooks at Elementary Schools in Turkey. 
Novitas-Royal (Research on Youth Language), 4 (2), 182-189

Choudhury, M. H. (2013). Teaching culture in EFL: Implications, challenges and strategies. IOSR Journal of Humanities and Social Science, 13 (1), 21.

Cohen, L., Manion, L., \& Morrison, K. (2007). Research Methods in Education. New York: Routledge.

Corbett, J. (2003). An Intercultural Approach to English Language Teaching (Languages for Intercultural Communication and Education). Clevedon: Multilingual Matters Ltd.

Crawford, J. (2002). The role of materials in the language classroom: Finding the balance. In J. Richards \& W. Renandya (eds). Methodology in language teaching: An anthology of current practice, 80-91.

Dai, L. (2011). Practical Techniques for Cultural-based Language Teaching in the EFL Classroom. Journal of Language Teaching \& Research, 2 (5), 1031-1036.

Gunantar, D. A. (2017). Textbooks Analysis: Analyzing English as a Foreign Language (EFL) Textbooks from the Perspective of Indonesian Culture. Journal of Language and Literature, 11 (2), 173-182.

Hatoss, A. (2004). A Model for Evaluating Textbooks. Babel, 39 (2), 25-32.

Hermawan, B., \&Noerkhasanah, L. (2012). Trace of culture in English textbooks for primary education. Indonesian Journal of Applied Linguistics, 1 (2), 49-60.

Jiang, W. (2000). The relationship between culture and language. ELT journal, 54 (4), 328-334.
Kramsch, C., \& Sullivan, P. (1996). Appropriate pedagogy. ELT Journal50 (3), 199-212.

Lappalainen, T. (2011). Presentation of the American culture in EFL textbooks: An analysis of the cultural content of Finnish EFL textbooks for secondary and upper secondary education. (Master's Thesis). University of Jyväskylä, Finland. Retrieved February 4, 2018 from https:??jyx.jyu.fi/bitstream/handle/123 456789/1/URN.pdf

McDevitt, B. (2004). Negotiating the syllabus: A win-win situation?. ELT journal, 58(1), 3-9.

McKay, S. L. (2003). Toward an appropriate EIL pedagogy: Re-examining common ELT assumptions. International journal of applied linguistics, 13 (1), 1-22.

Pulverness, A. (2000). Distinctions \& Dichotomies culture-free, culturebound. English Teaching Professional, (14), 17.

Santosa, I. (2015). Cultural Representation in English Textbook for Junior Highschool. Eduscience, 1 (1), 31.

Sardi, C. (2002). On the Relationship between Culture and ELT. Studies about Languages, 3, 101-107.

Silberstein, S. (2001). Sociolinguistics. In D. Nunan \& R. Carter (Eds). The Cambridge guide to teaching English to speakers of other languages (pp. 101-106). Cambridge: Cambridge University Press.

Tomalin, B. (2008). Culture-the fifth language skill. Teaching English, 48 (1), 130-141.

Tseng, C. J., \& Chao, C. T. (2012). Teaching culture in Taiwan's EFL classroom. Procedia-Social and Behavioral Sciences, 47, 1843-1846. 
Tüm, G., \&Uğuz, S. (2014). An investigation on the cultural elements in a Turkish textbook for foreigners. ProcediaSocial and Behavioral Sciences, 158, 356-363.

Ur, P. (2009). A Course in Language Teaching: Practice and Theory. Cambridge: Cambridge

University Press.

Valdes, J. (1990). The inevitability of teaching and learning culture in a foreign language course. In $\mathrm{B}$. Harrison (Eds). Culture and the language classroom (pp. 20-30). Hong Kong, China: Modern English Publications.
Wardhaugh, R. (2006). An Introduction to Sociolinguistics $\left(4^{\text {th }}\right.$ ed $)$ Malden: Blackwell Publishing.

Xiao, J. (2010). Cultural Contents of an inuse EFL Textbook and English Major Students' Attitudes and Perceptions towards Cultures Learning at Jiangxi University of Science and Technology, China. (Master's Thesis). Prince of Songkla University, Songkhla, Thailand.

Yamanaka, N. (2006). An evaluation of English textbooks in Japan from the viewpoint of nations in the inner, outer, and expanding circles. JALTJournal, 28 (1), 55-57. 